\title{
How damaging is imprisonment in the long-term? A controlled experiment comparing long-term effects of community service and short custodial sentences on re-offending and social integration
}

\author{
Killias, Martin ; Gilliéron, Gwladys ; Villard, Françoise ; Poglia, Clara
}

DOI: https://doi.org/10.1007/s11292-010-9093-5

Posted at the Zurich Open Repository and Archive, University of Zurich ZORA URL: https://doi.org/10.5167/uzh-47454

Journal Article

Published Version

Originally published at:

Killias, Martin; Gilliéron, Gwladys; Villard, Françoise; Poglia, Clara (2010). How damaging is imprisonment in the long-term? A controlled experiment comparing long-term effects of community service and short custodial sentences on re-offending and social integration. Journal of Experimental Criminology, $6(2): 115-130$.

DOI: https://doi.org/10.1007/s11292-010-9093-5 


\title{
How damaging is imprisonment in the long-term? A controlled experiment comparing long-term effects of community service and short custodial sentences on re-offending and social integration
}

\author{
Martin Killias • Gwladys Gilliéron • \\ Françoise Villard • Clara Poglia \\ Published online: 29 March 2010 \\ (C) Springer Science+Business Media B.V. 2010
}

\begin{abstract}
Since the 19th century, short custodial sentences were said to foster reoffending through alienating inmates from families and work. The present study is one of the few randomized controlled trials comparing short custodial sentences with community service orders. Between 1993 and 1995, 123 subjects were randomly assigned to community service or immediate custody (of a maximum of 14 days) in the Lake of Geneva area (Switzerland). The present study updates results published earlier on a follow-up period of 2 years by considering re-convictions and social integration over 11 years. Although statistically not significant, re-offending was tentatively more common among ex-prisoners in the long run. Eleven years later, exprisoners were better off, complied better with tax regulations, and did not fare worse regarding employment history or marital status. In line with recent systematic reviews, the results do not confirm the wide-spread assumption that short custodial sanctions are harmful when compared to community service.
\end{abstract}

Keywords Community service $\cdot$ Randomized trial $\cdot$ Re-offending .

Short-term imprisonment $\cdot$ Social integration

\section{Introduction}

Since the writings of De Bonneville de Marsangy (1864) ${ }^{1}$, short custodial sentences were decried as harmful. They were said to not last long enough to cure inmates'

\footnotetext{
${ }^{1}$ The ideas of this pioneer were rapidly taken over by writers in many countries, but usually without crediting him for these merits. The German-Austrian Franz von Liszt (1889) was one among the few to refer explicitly to de Bonneville de Marsangy. We thank Professor André Kuhn, University of Lausanne, for having drawn our attention to this original source of a popular idea.
}

M. Killias $(\bowtie) \cdot$ G. Gilliéron

Institute of Criminology, University of Zurich, Rämistrasse 74/39, 8001 Zurich, Switzerland

e-mail: martin.killias@rwi.uzh.ch

F. Villard $\cdot$ C. Poglia

University of Lausanne, Lausanne, Switzerland 
"criminal disease" or to offer positive rewards through incapacitation, but to cut them off from their families and jobs and to expose them to contamination by (presumably worse) offenders. In order to overcome this "contagious" effect of short custodial sentences, community service has been introduced in many countries over the last decades. Although many dozens of quasi-experimental studies have reported lower rates of re-offending after community service compared to imprisonment, the question of whether community service has better rehabilitative effects can only be solved through randomized controlled trials that, unfortunately, are almost inexistent in this field ${ }^{2}$. Quasi-experiments tend to be systematically biased since subjects with better outlooks will more often qualify for community service or any other noncustodial sanction, whereas the worst subjects are likely to end up in prison. In a systematic review conducted under the umbrella of Campbell Collaboration, Villettaz et al. (2006) identified only five studies (out of a total of more than 300) that allowed, thanks to an experimental design, valid comparisons of the effects on re-offending of (short) custodial and community (i.e., non-custodial) sentences. Their meta-analysis based on these five valid studies showed that (short) imprisonment is not followed by re-offending more frequently than non-custodial or "alternative" sanctions. Shortcomings of the existing literature they identified include, beyond the lack of controlled randomized trials, the fact that comparisons of custodial and non-custodial sanctions are widely limited to comparing rates of reoffending (most of the time assessed through criminal records), that measures of social integration are largely absent and that follow-up periods rarely extend beyond 5 years. The absence of data on social integration is particularly deplorable since short custodial sanctions are said to produce higher re-offending rates through damaging side-effects on convicts' social networks.

The present study allows overcoming some of these shortcomings. It is based on a randomized controlled trial conducted between 1993 and 1995 in Switzerland with 123 subjects. The first results, covering a follow-up period of 2 years (Killias et al. 2000), showed lower re-offending rates for those assigned to community service. The present study extends the follow-up period to 11 years. It considers reconvictions and includes data on social and professional integration a decade after the sentence.

Before showing the results, we shall briefly review the existing literature and the way community service has been implemented in Switzerland. We shall also describe what legal arrangements made a controlled trial possible in a field that many observers tend to consider as unsuitable for experimental designs.

\section{Review of previous research}

\subsection{Community service as an "alternative" to custodial sanctions}

Community service is nowadays admitted in most European countries as a regular sentence. Switzerland was among the first countries to introduce it, in 1971, as a

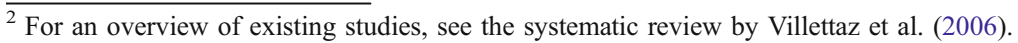


sanction available to minors, followed by England and Wales (in 1973) and many other countries where it was introduced as an alternative to short-term imprisonment (Harris and Wing Lo 2002). In 1991, community service has been introduced in the Swiss adult penal system as a form of executing short custodial sentences. In practice, about 4,000 (out of a total of some 10,000) immediate custodial sentences used to be executed per year under this form during recent years. In the new Swiss criminal code that became legally effective on January 1, 2007, community service is implemented as a regular sanction in sections 37-39. Community service can only be imposed with the convict's consent and takes place in a setting with a social aim. If the convict fails to comply, a community service order can be commuted into a day-fine or into a short custodial sanction. During the period of the present experiment, non-compliance was sanctioned by the Correctional Service, usually by transferring the defendant to a jail where short sentences were executed.

Community service has quickly been perceived as a desirable alternative to short custodial sentences (Junger-Tas 1994). To these concerns of rehabilitation came, more recently, economic considerations related to the costs of incarceration and possible benefits from community work (Harris and Wing Lo 2002; Muiluvuori 2001; Spaans 1998). Similar arguments were already present when, during the early 17 th century, somewhat comparable forms of community work became popular among legislators $^{3}$, although many would insist that community service has little to do with ancient forms that in many ways resembled forced labor. Whereas cost considerations seem intuitively plausible, little is known about the comparative effects of community service and short custodial sentences on re-offending and social integration. These issues will be addressed in the following sections.

\subsection{Previous studies on re-offending after community service and custodial sentences}

As Villettaz et al. (2006) stated after the review of more than 300 studies, the vast majority of quasi-experimental studies concluded that re-offending is more frequent after custodial than after "alternative" sentences including community service. For example, Muiluvuori (2001) found in a study conducted in Finland that $60.5 \%$ among those sentenced to community service re-offended during the follow-up period of 5 years, compared to $66.7 \%$ among those who served a custodial sentence. Though not significant, this difference is in line with findings from the Netherlands (Spaans 1998), Australia (Roeger 1994), and the United States (Smith and Akers 1993). Some authors also concluded that community service is particularly suitable for offenders without previous prison experience (Muiluvuori 2001).

The fact that the same favorable outcome has not been observed with experimental studies (Villettaz et al. 2006), points to a possible systematic selection bias in quasi-experimental evaluations. In practice, those in charge of programs like community service tend to favor consistently individuals with low risks of reoffending, and to place those with the worst records and future outlooks systematically in confinement. Evaluators have usually tried to control for such

\footnotetext{
${ }^{3}$ On the origins of "community" work (or, if one prefers, forced labor) in ancient Roman and Chinese law and the revival of such sanctions in continental Europe from the 16th century, see the references in Killias et al. (2008, par. 1331).
} 
influences by taking into account the number and, eventually, the kind of previous convictions including age at first court appearance, gender, and age. As Walker et al. (1981) showed, however, it is simply impossible to control for all variables that predict court disposition as well as re-offending and that usually are unrecorded, such as drug-addiction, alcohol-related problem behavior, work record, and family climate. As they concluded, this type of systematic bias can only be overcome through experimental studies with a random assignment of subjects to different penal regimes. Beyond a certain critical size, groups of individuals assigned randomly to different conditions can be considered as equal in all relevant respects before the start of the "treatment", and any difference that may be observed later can be causally interpreted as the effect of the differential "treatment" (Boruch 1997; Wilkins 1969). Since, even nowadays, experimental studies are rare (Farrington and Welsh 2006), no firm conclusions can be drawn regarding the effects of imprisonment compared to "alternative" penalties, despite hundreds of evaluation studies that have been identified through international reviews (Killias 2006; Smith et al. 2002; Villettaz et al. 2006).

However, even if valid previous research had been able to clearly establish the superiority of non-custodial sanctions, it would be hard to understand what might have produced the difference (Israel and Chui 2006). According to De Bonneville de Marsangy (1864) and other writers calling for the abolition of short custodial sentences, imprisonment is reputed harmful because it cuts off the convicted person from his family and work environment and jeopardizes his social re-integration. In other words, prison would provoke re-offending through damaging family and work-related social bonds to conventional society (Junger-Tas 1994). Interestingly, among the studies that evaluated prison and "alternative" sanctions, only a handful have ever looked at such variables, and those who did could not confirm such effects. Among them was the first evaluation of the experimental data used here (Killias et al. 2000). As it had turned out, prisoners did, following their sentence, not fare worse in job records, relations with other family members, or significant others. However, the mail survey conducted at that time suffered from substantial non-response (see below).

\subsection{The experimental design and legal arrangements}

The data used here are from a randomized controlled trial conducted in the Swiss Canton of Vaud (Lake Geneva area) from 1993 to 1995 and first evaluated in 1997. Originally, 141 defendants sentenced to a short custodial term (not exceeding 2 weeks) were randomly (with a probability of 5 against 2) assigned to either community service (100) or prison (41). Also included were a few fine defaulters whose fine had been commuted into a jail term not exceeding 2 weeks. Among those assigned to prison, two subjects had to be excluded from the analysis because they died (1) or emigrated ${ }^{4}$ (1) during the follow-up period. Among those who originally had been assigned to community service, two died and four emigrated during the observation period, three were excluded from the program ${ }^{5}$, two fine defaulters paid

\footnotetext{
${ }^{4}$ Immigrants were also eligible for the program. The emigration of five subjects in all was, statistically speaking, not unusual considering the length of the observation period.

${ }^{5}$ Reasons for exclusion were serious offending or serious violations of rules related to community service.
} 
their fine before starting community service ${ }^{6}$ and five opted, in the end, for custody (half-way house) rather than community service ${ }^{7}$. In sum, 84 among 100 subjects originally assigned to community service and 39 out of 41 assigned to serve their sentence in jail were available for analysis ${ }^{8}$.

The experimental design was made possible thanks to a fortunate legal surrounding. Switzerland had adopted in 1971 (and without any real debate) an amendment to the criminal $\operatorname{code}^{9}$ that entitled the federal government to allow, locally and for limited periods of time ${ }^{10}$, the introduction of new forms of punishment. This provision made the introduction of community service - as a form of executing short sentences of a few weeks-legally possible. The government ordinance that regulated such experiments required the outcomes to be evaluated. Although nobody probably had, in 1971, ever envisaged random assignment of subjects, there is obviously no legal obstacle to such a design. Given that participation in any new form of execution of sentences (and, therefore, also of community service) has always been voluntary, any subject who was not satisfied with the random design (or any other feature of the arrangement) could insist on being treated according to the law-and serve his sentence in prison, as ordered by the court ${ }^{11}$. Community service, as most other experimental programs as well, had limited capacity and could, therefore, not accommodate all possible candidates ${ }^{12}$. Given these arrangements, nobody was legally entitled to claim serving his sentence under a particular form, such as community work instead of going to prison. Despite all these legal safeguards, resistance to a controlled trial was formidable at the beginning. Opponents included social workers running the programme, administrators (particularly at the federal level), and some newspapers. It was only thanks to the commitment to evidence-based policy-making of the then director of local correctional services and a courageous Minister of Justice in the Canton of Vaud that the political support could be found to make such a design feasible ${ }^{13}$.

\footnotetext{
${ }^{6}$ According to Swiss Penal Law, unpaid fines are to be commuted into custodial sentences. The defendant escapes this consequence if he pays the fine before the custodial sentence (or the community service) is being executed.

${ }^{7}$ Opting for custody was "attractive" for originally unemployed subjects who managed to find a job before they had served the community service order. Since these subjects received the "opposite" treatment (rather than simply not the treatment they were assigned to), it was decided to exclude them from the analysis.

${ }^{8}$ For details regarding the number of drop-outs, see the publication covering the first follow-up period of 2 years (Killias et al. 2000b).

${ }^{9}$ Article 397 bis par. 4 that is now replaced by article 387 par. 4 a of the new criminal code.

${ }^{10}$ In practice, however, these two limitations were not very narrowly interpreted. Community service was introduced in 1991 and gradually extended to almost all cantons, and it has nowhere been discontinued before community service became a standard sanction with the new criminal code introduced in 2007.

${ }^{11}$ Theoretically, the voluntary character of participation in this programs reduced somewhat the evaluation's external validity (we do, indeed, not know how those fared who opted for prison), but left the internal validity unaffected. Although crucial in legal respects, the practical importance of having a voluntary program was minimal, however, because very few eligible candidates refused to participate.

${ }^{12}$ Weisburd (2000) argues that random assignment is easier to justify whenever the capacity of a new program is insufficient to accommodate all volunteers.

${ }^{13}$ André Vallotton was Director of Corrections and Claude Ruey Minister of Justice of the Canton of Vaud.
} 
Three factors probably helped in gaining support. One was to make eligible only candidates whose immediate custodial sentences did not exceed 2 weeks ${ }^{14}$. A second compromise was to change the odds of being assigned to community service from 1 in 2 to 5 in 7, thus reducing the number of subjects assigned to the "damaging" prison condition from one-half to less than one-third. Equally important, especially in gaining support among social workers and all those in charge of the program, was the provision that one candidate in five could be purposefully assigned to community service without passing the randomization process. Such a procedure was first recommended by Wilkins (1969) as a way to make randomization more acceptable to those running the program, and to reduce the risks of illegitimate manipulations of the random assignment process. The purposefully assigned subjects were included in the first evaluation, but analyzed separately in order to protect the experiment's internal validity ${ }^{15}$. All the others were assigned through random numbers provided by the evaluation team. This procedure was adopted to keep the assignment out of the control of those directly in charge of the program.

Randomized trials, as brilliantly illustrated by Joan McCord's (1990) study on the long-term outcomes of the Cambridge-Somerville experiment, offer the double advantage of allowing a new evaluation years later, extending the comparison to long periods of time, and to take into account dependant variables that had originally not been envisaged, such as success or failure in later life (unemployment, social welfare, income, etc.). In the present follow-up study, we shall look at re-offending over 11 years, and see what the subjects have become over this period in relation to work, marriage, income, and debts. It is probably one of the first studies that ever compared two sanctions over such long a period taking into account so many aspects of social integration beyond re-offending.

\section{The present study}

\subsection{The follow-up design}

The analyses conducted in 1997 found, in the first place, no significant inter-group differences in reconviction rates and new offences appearing in police files. However, when the evolution over time (i.e., the improvement after 2 years compared to an equal pre-intervention reference period) was considered, the reduction of individual (incidence) rates of offending was larger among those who were assigned to community work than among those who were sent to prison. The respective improvement was $71 \%$ vs. $59 \%$ in annual numbers of convictions, and $44 \%$ vs. $23 \%$ according to police data (Killias et al. 2000). The first difference was not significant, the second was close to significance at $p<.07$. In the present study,

\footnotetext{
${ }^{14}$ Such short sentences were quite popular among judges in Switzerland at that time, especially in cases of traffic offences (DWI), minor drug offences, or shoplifting, including other forms of minor thefts.

${ }^{15}$ This group (of 36 subjects) was interesting because it allowed identifying the factors considered as important by those in charge of the program. As it turned out, non-randomly admitted subjects were particularly low risk and/or lived under unusually difficult circumstances. The group as a whole fared somewhat better than the two randomized groups (for details, see Killias et al. 2000).
} 
the first priority is to see whether community service is still followed by lower reoffending rates more than a decade later.

\subsection{Data on re-offending}

Using the codes of all participants in the original experiment, we obtained, through the competent services ${ }^{16}$, a complete search of convictions registered in the national records kept by the Federal Office of Justice. These data were received anonymously, with the appropriate individual code that enabled to link the new data with those from the first evaluation. An effort was also made to collect data on re-offending in the police files of the Canton of Vaud. Unfortunately, however, the police files we had access to do not include traffic offences and were, therefore, of little help in assessing subjects' later biographies.

As it turned out that re-offending rates differed between the two groups over time, the results will be presented separately for the first and the second postintervention period of 5 and respectively 6 years, as well as for the entire period of 11 years. The point of "departure" is, in this as in the previous evaluation, the day a subject was randomly assigned either to community service or to prison. It would have been difficult to know in each case the exact date the sentence was finally executed ${ }^{17}$. Whatever may be said in favor of this or alternative options, the issue is obviously of marginal importance considering the entire "time at risk" (of 11 years).

The revisited population has slightly decreased since the 1997 study because five participants died since 1997 and were, thus, eliminated from registers. The community service group decreased from 84 people to 80 subjects, and the group assigned to prison from 39 to 38 .

\subsection{Data on social integration}

As stated above, imprisonment has been considered as harmful because it separates, for a short period at least, individuals from their families and their work. For this reason, it has been said to deteriorate offenders' family life and work record. In order to test outcomes in these areas, a survey was first envisaged but finally abandoned. An earlier survey had been conducted immediately once subjects had served the time of their sentence (Killias et al. 2000 ), but suffered from substantial non-response (50\% among prisoners and 35\% among those assigned to community service). A new survey would certainly have encountered even larger difficulties, beyond ethical problems in re-contacting former convicts so many years later.

For this reason, we asked for (and finally obtained) permission to search the files of the Internal Revenue Service (IRS) of the Canton of Vaud. These records include

\footnotetext{
${ }^{16}$ Thanks are due to Mr. Roger Dolder, head of the criminal record services, and Dr. Bernardo Stadelmann of the Federal Office of Justice for having efficiently conducted this search. We also thank the Correctional Services of the Canton of Vaud for having provided the details that allowed searching for participants in the registers.

${ }^{17}$ Especially in the case of community service, the execution of the sentence extended sometimes over longer periods.
} 
data on income, property, debts and welfare benefits, employment, marriage, separation, divorce, and number of children. These data are presumably more reliable to assess the standard of living and personal life circumstances than information retrieved from interviews ever might be. The data were made anonymous immediately after having been retrieved ${ }^{18}$.

\subsection{Data analysis}

Considering the relatively small sample size, a $p$ value of .10 was used as the threshold for significance. Using the usual $p<.05$ rule produces, in small experiments like this, unreasonably high risks of type-two errors (Weisburd 2000). Since randomized experiments allow straightforward and relatively simple data analyses, and considering the relatively small size particularly of the group assigned to custody, only Chi-squared tests have been used.

\section{Results}

\subsection{Prevalence of re-convictions after 11 years}

Table 1 gives the percentage of subjects who were re-convicted at least once during the first 5 years following random assignment to either community service or custody, during the following 6 years (i.e., from 5 to 11 years after random assignment) and over the entire period of 11 years.

According to Table 1, re-offending does not differ significantly between the two groups, neither during the first nor during the second period, nor over the entire period of observation. However, there is a tendency that re-offending is less common among those assigned to community service during the first 5 years. This matches what had been observed for the first 2 years by Killias et al. (2000). However, the trend is reversed during the second period. Although both groups had very similar rates of re-offending over the entire period of 11 years, re-convictions were more frequent among ex-prisoners during the first 5 years, whereas the opposite was true during the second period. Both groups reduced offending during the first 5 years, compared to pre-intervention levels. During the second period, however, only exprisoners continued to reduce re-offending, whereas re-conviction rates among those assigned to community service remained stable.

\subsection{Number (incidence) and seriousness of new convictions}

A program may be successful not only if it succeeds in reducing the number of subjects who continue to offend but also if it contributes to reducing the number of offences committed. We have, therefore, also looked at the number of new convictions (verdicts), but it turned out that those who were reconvicted were so

\footnotetext{
${ }^{18}$ We sincerely thank Mr. Philippe Maillard, Head of the Internal Revenue Service, for having permitted the search of the 118 subject's IRS records and, thus, to have made possible to include data on life circumstances.
} 
Table 1 Subjects with at least one new conviction during the first 5 and the following 6 years after random assignment and during the entire period of 11 years, by type of sanction (community service vs. short custodial sentence) (in \%)

\begin{tabular}{llll}
\hline & $\begin{array}{l}\text { Subjects with one new } \\
\text { conviction at least, within } \\
\text { the first 5 years }\end{array}$ & $\begin{array}{l}\text { Subjects with one new } \\
\text { conviction at least, after } \\
5 \text { years }\end{array}$ & $\begin{array}{l}\text { Subjects with one new } \\
\text { conviction at least, after } \\
11 \text { years }\end{array}$ \\
\hline $\begin{array}{l}\text { Custodial group } \\
n=38\end{array}$ & $39 \%(15)$ & $24 \%(9)$ & $58 \%(22)$ \\
$\begin{array}{l}\text { Community service group } \\
n=80\end{array}$ & $35 \%(28)$ & $37 \%(29)$ & $53 \%(41)$ \\
& $\chi^{2}=0.223$ & $\chi^{2}=1.874$ & $\chi^{2}=0.293$ \\
$d f=1$ & $d f=1$ & $d f=1$ \\
$N S$ & $N S$ & $N S$ \\
\hline
\end{tabular}

for one offence only ${ }^{19}$. Thus, looking at number of re-convictions did not change the conclusions reached from prevalence rates (shown in Table 1). Further analyses regarding the types of new convictions did not permit to observe any shifts in seriousness of offences, because most subjects had been convicted and re-convicted for traffic offences (such as drunken driving), minor thefts, and/or minor drug offences $^{20}$.

\subsection{Social integration 10 years later according to tax payers' records}

Not all subjects who participated in the experiment could be located in the files of the Internal Revenue Service (IRS) of the Canton of Vaud. Among ex-prisoners, 29 out of 38 subjects could be located. Among the 80 subjects assigned to community work, only 50 have been found, however. Some may have left the Canton of Vaud, or live under such marginal circumstances that the Internal Revenue Service does not care about their record. Usually, any taxpayer who fails to file a tax declaration may first be warned, then fined and, ultimately, taxed directly by the IRS on the base of estimated revenues. This happened with five subjects of the ex-prison group, and 14 among those of the community service group. These 19 files turned out to be very incomplete, however, in particular regarding social background. Therefore, only the files of those who had filed a tax declaration sheet for 2004 have been included. (Our search in the files of the Internal Revenue Service occurred during 2006, i.e., long after the 2004 tax declaration sheets were due.). The details appear in Table 2.

As Table 2 reveals, subjects from the community service group were less likely to be known to the IRS, and if they were, they were less likely to file a tax declaration

\footnotetext{
${ }^{19}$ The incidence rates were, therefore, identical with prevalence rates (as given in Table 1), namely .39 for those assigned to jail during the first 5 and .24 during the following period, and .35 for those assigned to community service during the first and .37 during the second period.

${ }^{20}$ For the period between 6 and 11 years, detailed data on offences are available. Traffic offences (mostly DWI) represented $55 \%$, drug offences (usually consumption) $24 \%$, criminal code offences (mostly minor theft) $19 \%$ and offences according to other laws $2 \%$. Since these are typically the offences leading, at that time, to short prison sentences, it is likely that this distribution characterized the population from the beginning.
} 
Table 2 Subjects located in the files of the Internal Revenue Service (IRS) of the Canton of Vaud (year searched: 2004), by type of sanction

\begin{tabular}{lllll}
\hline & $\begin{array}{l}\text { Subjects included } \\
\text { in the 1997 study }\end{array}$ & $\begin{array}{l}\text { Subjects relocated for } \\
\text { the present study }\end{array}$ & $\begin{array}{l}\text { Subjects known } \\
\text { to the IRS }\end{array}$ & $\begin{array}{l}\text { Subjects who filed } \\
\text { a tax declaration }\end{array}$ \\
\hline $\begin{array}{l}\text { Custodial group } \\
\begin{array}{l}\text { Community service } \\
\text { group }\end{array}\end{array}$ & $100 \%(39)$ & $97 \%(38)$ & $74 \% *(29)$ & $62 \% * *(24)$ \\
$\begin{array}{l}\text { Total } \\
100 \%(84)\end{array}$ & $95 \%(80)$ & $60 \% *(50)$ & $43 \% * *(36)$ \\
& $100 \%(123)$ & $96 \%(118)$ & $64 \%(79)$ & $49 \%(60)$
\end{tabular}

$*\left(\chi^{2}=2.551, d f=1, N S\right) * *\left(\chi^{2}=3.720, d f=1, p<0.1\right)$

than ex-prisoners. Overall, former prisoners had filed more often a tax declaration $(62 \%)$ than those who served community work $(43 \%)$, this difference being marginally significant (at $p<.10$ ). Although the fact of not being known to the IRS might also be related to geographic mobility (i.e. moving out of the Canton of Vaud ${ }^{21}$, the fact that those assigned to community service were also more often taxed on the base of incomes estimated by the IRS points to a possibly lower compliance with legal obligations in this group. Filing a tax declaration and having a taxpayer's record certainly is an indicator of social integration as such. As the results given in Table 2 suggest, ex-prisoners are apparently less disintegrated a decade after having served their sentence than those who were randomly assigned to community service.

The fact that the IRS records are incomplete should, therefore, not be seen as a threat to the validity of the following analyses. Since the IRS usually makes every effort to include in its files subjects of even marginal interest, we may reasonably assume that those without an IRS file were less well off than taxpayers who complied with regulations. Therefore, the following analyses are probably conservative since they likely underestimate the true extent of the differences in social integration that appear in the Table 3.

\subsection{Life circumstances}

The records of the IRS allow seeing whether subjects in our study were married, separated, divorced, or single in 2004 , i.e., nearly a decade after the original experiment. They also allowed seeing the subjects' employment and financial situation. The results are presented in Table 3.

Regarding being single, married, or divorced/separated, there are no significant inter-group differences over all three conditions. In terms of social integration, the results are somewhat ambiguous: if the focus is on "failure", divorce and separation are more common among ex-prisoners; if, however, the focus is on entering marriage, ex-prisoners seem to be more successfully integrated. Between 1997 and 2004 , there were more marriages ( $21 \%$ vs. $11 \%)$, but also more divorces/separations

\footnotetext{
${ }^{21}$ We cannot strictly exclude that mobility to other cantons was more common among those assigned to community service (we do not know subjects' addresses). On the other hand, it is not plausible why community service should have "driven" subjects to other cantons more often than former prisoners.
} 
(17\% vs. $3 \%$ ) among ex-prisoners than in the community service group. Thus, the fact that more prisoners were ever married cannot be attributed to pre-existing differences at the time subjects had been assigned to a sanction. If divorce occurred more frequently among ex-prisoners, this may reflect the fact that prisoners entered marriage more often than those in the community service group. On balance, both groups live in a marriage at the same rate $(33 \%)$.

Concerning subjects' current professional situation, none of the inter-group differences reaches statistical significance. However, it seems that more people are out of work or disabled among those who were assigned to community service. Even if the difference is not significant, it goes in the opposite direction of what has been suggested in the literature, namely that even short-term imprisonment negatively affects inmates' later professional careers. Between 1997 and 2004, there was no deterioration of the employment situation in both groups, although the community service group experienced some improvement slightly more often.

Table 3 Subjects' social integration in 2004, by type of sanction

\begin{tabular}{|c|c|c|c|c|c|}
\hline & Categories & $\begin{array}{l}\text { Custodial } \\
\text { group }\end{array}$ & $\begin{array}{l}\text { Community } \\
\text { service group }\end{array}$ & Total & $p$-value \\
\hline \multirow{4}{*}{$\begin{array}{l}\text { Marriage status among } \\
\text { subjects of both groups } \\
\text { in } 2004\end{array}$} & Single & $42 \%$ & $58 \%$ & $52 \%$ & $\chi^{2}=3.441$ \\
\hline & Married & $33 \%$ & $33 \%$ & $33 \%$ & $d f=2$ \\
\hline & $\begin{array}{l}\text { Divorced/ } \\
\text { separated }\end{array}$ & $25 \%$ & $8 \%$ & $15 \%$ & $N S$ \\
\hline & Total & $100 \%(24)$ & $100 \%(36)$ & $100 \%(60)$ & \\
\hline \multirow{3}{*}{$\begin{array}{l}\text { Professional situation } \\
\text { among subjects of both } \\
\text { groups in } 2004 \text {, without } \\
\text { retired subjects }\end{array}$} & $\begin{array}{l}\text { Employed/ } \\
\text { self-employed }\end{array}$ & $91 \%$ & $81 \%$ & $85 \%$ & $\chi^{2}=0.984$ \\
\hline & $\begin{array}{l}\text { Unemployed/ } \\
\text { disabled }\end{array}$ & $9 \%$ & $19 \%$ & $15 \%$ & $d f=1$ \\
\hline & Total & $100 \%(22)$ & $100 \%(26)$ & $100 \%(48)$ & $N S$ \\
\hline \multirow[t]{4}{*}{$\begin{array}{l}\text { Change in the professional } \\
\text { situation in both groups } \\
\text { since the correctional } \\
\text { experience }\end{array}$} & $\begin{array}{l}\text { Unemployed } \\
\text { at t-1, but } \\
\text { employed in } \\
2004\end{array}$ & $32 \%$ & $42 \%$ & $38 \%$ & $\chi^{2}=0.559$ \\
\hline & No change & $68 \%$ & $58 \%$ & $62 \%$ & $d f=1$ \\
\hline & $\begin{array}{l}\text { Employed } \\
\text { at } t-1 \text {, but } \\
\text { unemployed } \\
\text { in } 2004\end{array}$ & - & - & - & $N S$ \\
\hline & Total & $100 \%(22)$ & $100 \%(26)$ & $100 \%(48)$ & \\
\hline \multirow{3}{*}{$\begin{array}{l}\text { Income after deductions } \\
\text { for family charges and } \\
\text { other deductible expenses } \\
\text { in both groups in } 2004\end{array}$} & $\begin{array}{c}\text { No or negative } \\
\text { income }(<0)\end{array}$ & $0 \% *$ & $17 \% *$ & $10 \%$ & $* \chi^{2}=4.444$ \\
\hline & $\begin{array}{l}\text { Positive } \\
\text { income }(>0)\end{array}$ & $100 \% *$ & $83 \% *$ & $90 \%$ & $d f=1$ \\
\hline & Total & $100 \%(24)$ & $100 \%(36)$ & $100 \%(60)$ & $p<.05$ \\
\hline
\end{tabular}


With respect to subjects' financial circumstances, Table 3 shows that $17 \%$ among those assigned to community service (but none among the ex-prisoners) had "negative" incomes in 2004, i.e., lived on incomes whose sum, after deductions for family charges and other deductible expenses, was lower than 0. Despite the small absolute numbers, this difference was significant (Chi-squared test, 4.44, $p<.05$ ). This means that subjects originally assigned to community service live under more extreme financial circumstances than those who had been sent to jail. Regarding debts, no significant differences have been observed, with 33\% among ex-prisoners and 36\% among those assigned to community service were having debts that exceeded their property. As stated above, the fact that many subjects having been assigned to community service are missing in IRS files may lead to the underestimation of these differences.

\section{Discussion}

The results suggest that community service does not reduce the odds of later reoffending or improve social integration when compared to imprisonment. Although only two out of 12 inter-group differences are significant (even when the threshold is relaxed to $p<.10$ ), the two significant and six out of ten non-significant comparisons are favoring the ex-prisoners' group, particularly with respect to life circumstances. Even if the present findings do not support claims that (short-term) imprisonment works, they nonetheless disconfirm earlier theories attributing harmful effects to this sanction. Of course, this outcome is perfectly plausible since an intervention of no more than 2 weeks in prison (or community service of equal duration) is, in practical terms, so weak that any larger effect in the longer run would seem unlikely. However, 19th-century writers on the subject argued that short custodial sanctions negatively affect social integration and increase the odds of re-offending, and European criminal justice policy makers have, throughout the last 50 years, largely accepted the idea that imprisonment even of a few weeks or days might be damaging and should, therefore, be avoided at almost any costs. Studying the outcomes of short custodial sanctions in an experimental setting is, therefore, relevant to policy-making in Europe.

The present findings on social integration, based on Internal Revenue Service records, largely match observations made 10 years ago based on a survey conducted with our subjects shortly after they had served their time (Killias et al. 2000). At that time, social integration turned out to be comparable among both groups. This was inconsistent with the alleged harmful effects of short custodial sanctions, even if the results on re-offending at that time favored community service. Indeed, the theory suggested that short custodial sanctions increase the odds of re-offending through weakening social bonds to employment and the family. Therefore, the correlation should have been stronger between type of sanction and these ties than between sanction type and re-offending. Thus, the earlier study suggested that re-offending is not mediated by weakened social bonds to the family or the work environment. According to the present study, short custodial sanctions neither affect social integration nor re-offending in the longer run.

Consistent with the findings of our earlier study, we found that ex-prisoners reoffended somewhat more often during the first 5 years compared to those assigned to community service. It was during the second period (after 5 and up to 11 years) that 
the trend was reversed. Twelve years ago, it was suggested that the Hawthorn effect may have favored the experimental (i.e., new) sanction over the traditional one in the short run $^{22}$. Given that virtually all of the 123 participants hoped being assigned to community service, one may assume that those who drew the "good" lot felt happier than those randomly sent to prison. The ex-prisoners felt, 2 years later, far less satisfied with their experience, they felt more often angry about the police and the judge who had dealt with their case and they rejected more often the idea of having had a "debt" to pay to society. Response to the survey was also significantly better among those assigned to community work. In sum, the type of sanction did not seem to influence social integration, but attitudes towards the criminal justice system. In the follow-up study presented here, no survey could be conducted, and no data are, therefore, available on attitudes among subjects. That inter-group differences regarding re-offending have disappeared a decade later is plausible, given that frustration about having drawn the "bad" lot may have faded away with time.

In conclusion, it is hard to say why custodial sanctions may positively affect social integration in the long run, as with respect to income or meeting the requirements of the Internal Revenue Service. Given that many among the subjects in both groups had been convicted for driving while intoxicated or for drug-offences, one may speculate from experiences in the treatment of addictions that a "tough" experience like a short custodial period may, eventually, better motivate subjects to change than a new "warning" in an endless chain of similar experiences (Klingemann and Carter Sobell 2006). Some qualitative observations in the center where community service is being served in most of the cases in the Canton of Vaud offer additional support to such considerations (Périsset and Vuille 2006). Subjects who served their community service sentences in that center worked often together and had plenty of opportunities to offer each-other mutual support in developing all sorts of rationalizations. If this should hold relevant, it would add to the growing body of research pointing to possible flaws in programs based on "group therapy" or similar arrangements (Farrington and Welsh 2006). Given the widely non-significant inter-group differences and the rather weak statistical power of this randomized controlled trial, this issue has to remain undecided, however.

Of course, the results presented here must be seen in connection with the short duration of incarceration among those who were randomly assigned to custody. None among our subjects underwent incarceration for more than 2 weeks, and most were eligible for serving their time in a half-way house, i.e., they were allowed to leave the correctional facility every working day to pursue their job, and spent leisure time and weekends in isolation from other inmates. Longer periods of imprisonment may be far more harmful both for employment careers and for family relations. Observations of damaging effects of imprisonment on the odds of divorce/separation and reduced chances of getting married (Western 2006), on later job careers and on wages (Bushway 1998; Grogger 1995; Nagin and Waldfogel 1998; Western et al. 2001; Western 2006) may, therefore, remain perfectly valid.

\footnotetext{
${ }^{22}$ Thanks are due to Dr. Frank Vitaro (University of Montreal) and Dr. Robert F. Boruch (University of Pennsylvania) for having drawn our attention to this possibility.
} 


\section{Conclusions}

This experiment addresses some of the questions that were raised one and a half century ago, but that were hardly ever studied through randomized controlled trials. The outcomes largely contradict what had been suggested during the 19th century, and widely accepted by researchers and policy-makers ever since, namely that short custodial sanctions negatively affect bonds to conventional society and favor, indirectly, re-offending and future criminal careers.

These results come at a time when many legislators throughout Europe, following recommendations of the Council of Europe, have abolished or reduced short prison sentences. They have been replaced, in theory, by all sorts of "alternative" sanctions such as community service, in practice, however, often by longer prison sentences (Kuhn 2000). Net-widening effects, such as substitution of suspended custodial and other "mild" sanctions by community work, have been empirically documented in several countries (Killias et al. 2000a; Spaans 1998). Ironically, the policies of the last 20 years may have removed from the criminal codes a sanction that in all likelihood is not harmful ${ }^{23}$, and replaced it by long sentences that, as intuition and at least one major review (Gendreau et al. 1996) suggest, may be far more desintegrating than short sentences ever could have been.

A single experiment like this cannot answer concerns related to the findings' external validity, left alone that the present trial included only volunteers (as described above). For this sake, systematic reviews and meta-analyses are helpful ways out of the dilemma, as illustrated by Gendreau et al. (1996) and Villettaz et al. (2006). To the extent meta-analyses are restricted to high-quality studies, their results match the present findings, in the sense that they could not confirm any damaging effects of (short) custodial sentences compared to alternative (i.e., non-custodial) sanctions. This lends some confidence to our findings that, otherwise and given the low statistical power of a small randomised controlled trial, might be far more questionable.

Research showing that one sanction type is no more harmful than another one leaves policy-makers room for paying attention to other considerations, such as equity, costs, and efficiency. Our results suggest that legislators should no longer suppress short prison sentences arguing that they are harmful, and pay more attention to aspects beyond special deterrence and rehabilitation.

\section{References}

Boruch, R. F. (1997). Randomized Experiments for Planning and Evaluation: A Practical Guide. Thousand Oaks: Sage.

Bushway, S. D. (1998). The impact of an arrest on the job stability of young white American men. Journal of Research in Crime and Delinquency, 35, 454-479.

Council of Europe, Resolution (73)17 on the short-term treatment of adult offenders, 13 April 1973

De Bonneville de Marsangy, A. (1864). De l'amélioration de la loi criminelle en vue d'une justice plus prompte, plus efficace, plus généreuse et plus moralisante, vol. II. (On amending penal law by making it swifter, more efficient, more generous and more moralizing.). Paris: Cosse and Marchal.

\footnotetext{
${ }^{23}$ Particularly if such sentences can be served in a halfway house where professional activities can be continued under the day and inmates are being locked up only overnight and during weekends.
} 
Farrington, D. P., \& Welsh, B. C. (2006). A half-century of randomized experiments on crime and justice. Crime and Justice, 34, 55-132.

Gendreau, P., Little, T., \& Goggin, C. (1996). A meta-analysis of the predictors of adult offender recidivism: what works! Criminology, 4, 575-608.

Grogger, J. (1995). The effects of arrests on the employment and earnings of young men. Quarterly Journal of Economics, 110, 51-71.

Harris, R. J., \& Wing Lo, T. (2002). Community service: Its use in criminal justice. International Journal of Offender Therapy and Comparative Criminology, 46, 427-444.

Israel, M., \& Chui, W. H. (2006). If something works' is the answer, what is the question? Supporting pluralist evaluation in community corrections in the United Kingdom. European Journal of Criminology, 3, 181-200.

Junger-Tas, J. (1994). Alternatives to Prison Sentences: Experiences and Developments. Amsterdam/New York: Kugler.

Killias, M. (2006). Improving impact evaluations through randomised experiments: the challenge of the NRC Report for European Criminology. Journal of Experimental Criminology, 2, 375-391.

Killias, M., Aebi, M. F., \& Ribeaud, D. (2000). Does community service rehabilitate better than short-term imprisonment? Results of a controlled experiment. The Howard Journal of Criminal Justice, 39, 4057.

Killias, M., Camathias, P., \& Stump, B. (2000a). Alternativsanktionen und der,Net-Widening'-Effekt. Ein quasi-experimenteller Test: Unerwartete Wirkungen in der Gemeinnützigen Arbeit auf die Strafzumessung in der Schweiz (Alternative Sanctions and the Net-Widening Effect: A QuasiExperimental Test. Unexpected Effects of Community Service on Sentencing in Switzerland.). Zeitschrift für die gesamte Strafrechtswissenschaft, 112, 637-652.

Killias, M., Kuhn, A., Dongois, N., \& Aebi, M. (2008). Grundriss des Allgemeinen Teils des Schweizerischen Strafgesetzbuchs (General Principles of Swiss Criminal Law). Bern: Stämpfli.

Klingemann, H., \& Carter Sobell, L. (Eds.). (2006). Selbstheilung von der Sucht (Spontaneous Remission from Addiction). Wiesbaden: VS Verlag für Sozialwissenschaften.

Kuhn, A. (2000). Détenus; Combien ? Pourquoi ? Que faire? (Inmates: How many? Why? What to do?). Bern: Haupt.

McCord, J. (1990). Crime in moral and social contexts. Criminology, 28, 1-26.

Muiluvuori, M.-L. (2001). Recidivism among people sentenced to community service in Finland. Journal of Scandinavian Studies in Criminology and Crime Prevention, 2, 72-82.

Nagin, D., \& Waldfogel, J. (1998). The effect of conviction on income through the life cycle. International Review of Law and Economics, 18, 25-40.

Périsset, C. \& Vuille, J. (2006). Le travail d'intérêt général dans le Canton de Vaud: Principes et évaluation (Community service in the Canton of Vaud. Concept and Evaluation). MA dissertation, University of Lausanne.

Roeger, L. S. (1994). The effectiveness of criminal justice sanctions for Aboriginal offenders. Australian and New Zealand Journal of Criminology, 27, 264-281.

Smith, L. G., \& Akers, R. L. (1993). A comparison of recidivism of Florida's community control and prison: a five-year survival analysis. Journal of Research in Crime and Delinquency, 30, $267-$ 292.

Smith, P., Goggin, C., \& Gendreau, P. (2002). Effets de l'incarcération et des sanctions intermédiaires sur la récidive: Effets généraux et différences individuelles. Ottawa: Sollicitor General of Canada.

Spaans, E. C. (1998). Community service in the Netherlands: its effects on recidivism and net-widening. International Criminal Justice Review, 8, 1-14.

Villettaz, P., Killias, M., \& Isabel, Z. (2006). The effects of custodial vs. non-custodial sanctions on re-offending. A systematic review of the state of knowledge. www.campbellcollaboration.org

Von Liszt, F. (1889). Kriminalpolitische Aufgaben (Challenges for crime policy). Zeitschrift für die gesamte Strafrechtswissenschaft, 9, 737-782.

Walker, N., Farrington, D. P., \& Tucker, G. (1981). Reconviction rates of adult males after different sentences. British Journal of Criminology, 21, 357-360.

Weisburd, D. (2000). Randomized experiments in criminal justice: prospects and problems. Crime and Delinquency, 46, 181-193.

Western, B. (2006). Punishment and Inequality in America. New York: Russell Sage Foundation Publications.

Western, B., Kling, J. R., \& Weiman, D. F. (2001). The labor market consequences of incarceration. Crime and Delinquency, 47, 410-427.

Wilkins, L. T. (1969). Evaluation of Penal Measures. New York: Random House. 
Martin Killias received a PhD in Law and a MA in sociology and social psychology from the University of Zurich. Currently, he is professor of criminal law and criminology at the University of Zurich. His work has centered on international crime and self-report surveys, the European Sourcebook of Crime and Criminal Justice Statistics, and evaluations including RCTs. He is a member of the Steering Committee of the Campbell Collaboration Crime and Justice Group. For over 24 years he served as a part-time judge at the Federal Supreme Court of Switzerland.

Gwladys Gilliéron received a $\mathrm{PhD}$ in Law from the University of Zurich and an LLM in Criminal Justice from the University of Lausanne. Currently, she is a research fellow at the University of Minnesota's Institute on Crime and Public Policy. She has been studying wrongful convictions in several nations and, more recently, outcomes of randomized controlled trials on new criminal sanctions.

Françoise Villard received a Master in Psychology and a Master Degree in Criminal Justice from the University of Lausanne. She has been working for several years as a clinical psychologist and is currently working for the rehabilitation of people with addiction problems.

Clara Poglia received a MLaw from the University of Geneva and an LLM in Criminal Justice from the University of Lausanne. She is currently working as attorney-at-law in Geneva. 